\title{
Daniel Rabel and the Grotesque
}

The disguised court entertainment accompanied by music and dancing which in England after 1604 became conventionally known as the masque was not necessarily tied to a program of idealization and order. Earlier English disguisings seem to have chiefly featured exotic costumes in which the performers entered the hall or chamber, accompanied by their torch-bearers, and danced to music for, and with, the assembled observers. These figures might be solemn and serious - Greek Worthies or King Arthur's knights ${ }^{1}$ - or light-hearted and amusing: in the same year that the Greek Worthies, with attendant satyrs as torch-bearers, appeared at the Edwardian court (1553), the property-maker John Carowe constructed elaborate floats representing six apes playing bagpipes. These were large, hollow, carnival figures, made of 'paste and Cemente mowlded' on wicker frames, and covered with 'gray Conyskynnes', within which actual bagpipers were concealed to produce the apes' music. This show, fairly evidently a simple parade, is referred to in the Revels accounts as a 'maske of bagpypes', as is the 'maske of tumblers' in the same season, which featured the venerable device of figures apparently walking on their hands, 'with leggpeces lyke armes and handes', still a favourite in the annual Santa Claus Parade in Toronto. ${ }^{2}$ The sixteenth-century English 'masks', then, could take a form as simple as a parade of disguised figures or of floats, and thus might be said to be nearer to the French ballets de cour, with their successive entrées of disguised dancers, many of them in comic or amusing costumes.

The ballet de cour of the reign of Louis XIII (1610-43) began to influence English aristocratic entertainments in the later Jacobean period; 3 French cultural influence generally increased when Louis' sister became the English queen in 1625. Thereafter the work of the chief French court designer, Daniel Rabel (d. 1637) appears to have been copied by the principal designer of the English Stuart court, Inigo Jones (1573-1652). ${ }^{4}$ A comparison between the surviving costume sketches of the two artists reveals a far wider and more fanciful range of devices at the French court, including amusing and grotesque 
inventions of all kinds. Traditional 'folk' jokes, such as the legless doublet (Somebody) and the trunkless breeches (Nobody), appeared as 'hocricanes' and 'hosnagues' in the Ballet Royal du Grand Bal de la Douairière de Billebahaut in February 1626, a motif known in Jacobean England in ballad and playbook illustrations, and in Barbican, London, as the shop sign of John Trundle, publisher and bookseller. 5 The exuberant humour of Rabel's designs suggests that the French court had maintained something of a sixteenth-century tradition of revels, while in England, as far as the story told by surviving masque texts and designs indicates, grotesquerie and caricature had been confined to the limited scope of the antimasques. However true this may be, it is demonstrable that Rabel was making conscious use of a sixteenth-century graphic tradition of the grotesque in creating his exaggerated comic figures.

One sixteenth-century designer and painter famous for his grotesque compositions was the Milanese Giuseppe Arcimboldo (1527-93), whose pictures of human faces composed from fruit, vegetables, other natural objects, and various artifacts are still widely known. Arcimboldo also made designs for tournament entertainments at the Hapsburg courts in the 1570s and 1580s. One surviving drawing, of a cook as torch-bearer, is composed from pots, pans, and ladles. ${ }^{6}$ This kind of composition was also known to Rabel, who designed, for example, several musician figures made from musical instruments, and an astrologer costumed in three dimensional representations of the zodiacal signs. ${ }^{7}$ Some of Rabel's other visual ideas came from outside France, although native French art had something of a tradition of grotesque exaggeration even before the widespread influence of Callot's etchings in the 1620s, an influence which spread to England, and the work of Inigo Jones. The strange figures published in 1565 by Richard Breton as Les songes drolatiques de Pantagruel are based on Cock's prints of Bruegel, ${ }^{8}$ and satirical woodcuts produced in Paris at about the same date show 'a marked taste for caricatured faces, if not downright deformed ones'. 'This taste was shared in Renaissance art more widely: Leonardo da Vinci did numerous sketches of grotesque heads, some of which were reproduced as prints.

If we consider Rabel's surviving sketch for the caricatured dowager duchess at the centre of the 1626 entertainment, 'La Douairière de Bilbahault' herself, now in the Theatre Museum in London (fig 1), we may see a curious female figure advancing to the left on platform shoes, with an oddly contorted posture, hands raised and elbows extended to the rear, enormous neck stretched upward, head and chin extended with aggressive reptilian solemnity. ${ }^{10}$ The general effect is of ridiculous dignity, but it is the face and neck - presumably a 


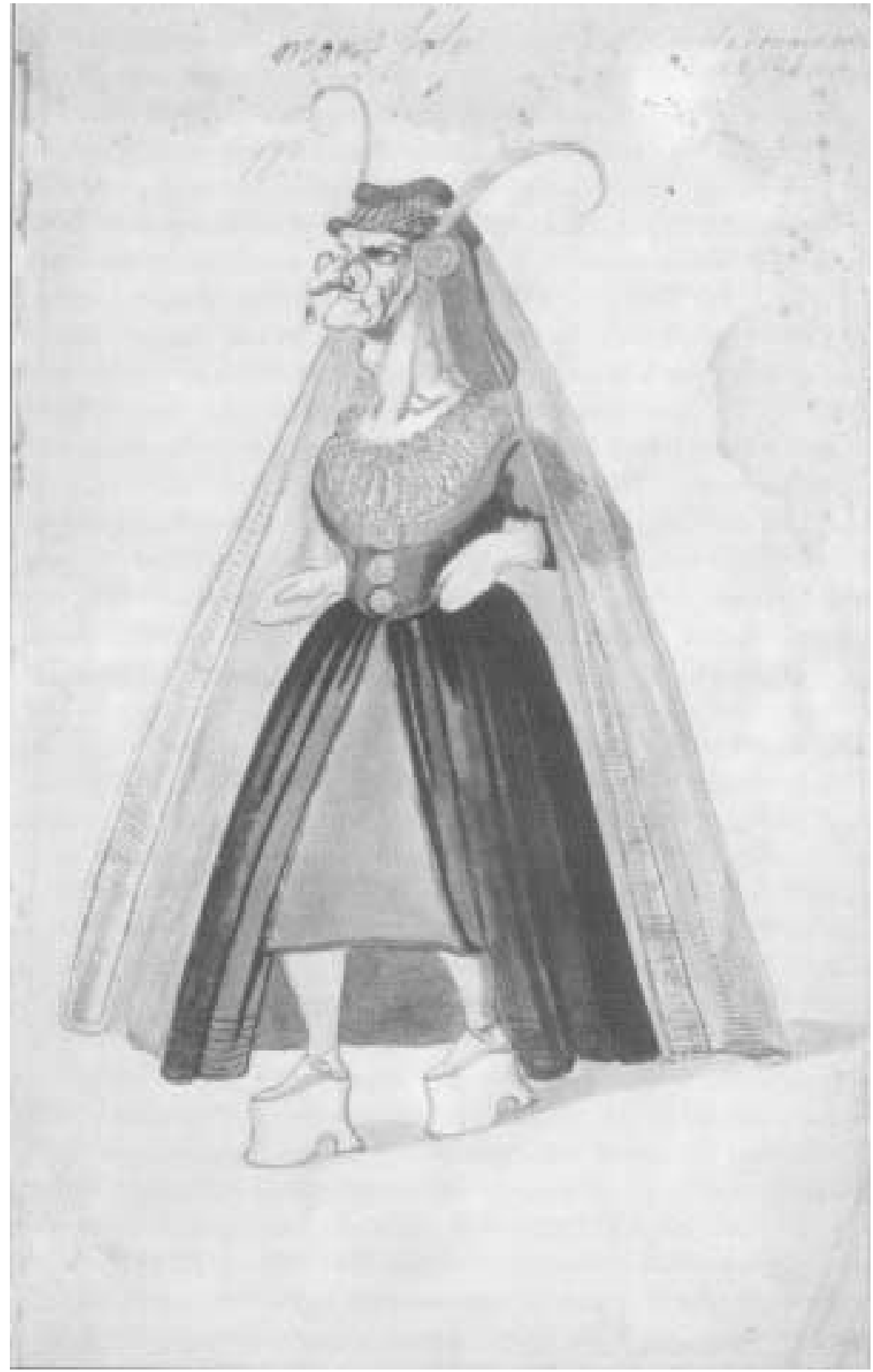

Fig 1. Daniel Rabel, costume drawing captioned 'La Douairière de Bilbahault', 1626. The Theatre Museum, courtesy Victoria \& Albert Museum 
mask in the performance itself, worn by Monsieur Joly, who danced the part - which crowns the comic impression. Head and neck are both grossly disproportionate to the size of the rest of the body, the thick neck is wattled and goitred, and the face features a prominent chin, toothless, sunken mouth, enormous protuding nose sporting a pendant dewdrop and large pince-nez, and glaring, sunken eyes under a heavy brow. All these exaggerated facial characteristics might be found in a series of related woodcuts by the south German artist Hans Weiditz (c 1500-36), one of a group of three German specialists in caricature and the grotesque working in the first half of the sixteenth century: the others are the Nuremberg printmakers Peter Flötner and Erhard Schön. The most complete collection of Weiditz's grotesque figure series to survive today is kept at the Kupferstichkabinett of the Schlossmuseum at Gotha, Germany. ${ }^{11}$ The woodcuts 'Mair Ulin and his Wife' and the 'Physician and Assistant' show the extreme facial distortions Rabel adopts: grotesquely swollen and disjointed necks, protuding chins, exaggerated hooked and drooping noses, and glaring, squinting eyes. ${ }^{12}$ Distortion affects the entire body of these figures, particularly amusingly in the Physician caricature, in which the sinuous lines of the protuberant bellies and crane-like necks are carried through in the curves of the feet and shoes, sword, and enormous urinal glass. The absurd motion suggested by the figures seems to have been picked up in Rabel's sketch, and there seems little doubt, particularly with regard to the face of his figure, that he must have had copies of the Weiditz prints before his eye as he composed. Similar exaggerations - paunches, hunchbacks, bent, swollen, and dwarfish figures with misshapen faces - may also be found in woodcuts by Flötner and Schön; the general style of early sixteenth-century south-German caricature provides a rich source for grotesque figures, suitable for copying for entertainments or other decorative applications. ${ }^{13}$

A further comic female design by Rabel for the same 1626 ballet probably draws on the same source as that for the Douairière. The drawing for the 'Novrices des Grenadins' (fig 2) shows a pair of wetnurses with swaddled babies slung across their backs, and with enormously elongated breasts, with which they can perform the singular accomplishment of breast-feeding their charges over their left shoulders. The figure on the left of the drawing illustrated, from the Louvre collections, also survives in a rather jollier coloured sketch, but with exactly the same pose: ${ }^{14}$ in both pictures the right breast hangs to the figure's waist or below, emerging freely from a sleeved garment open on either side of a central panel which extends from a yoke over the shoulders to a waistband below. This composition appears to draw on a third Weiditz woodcut (fig 3) 


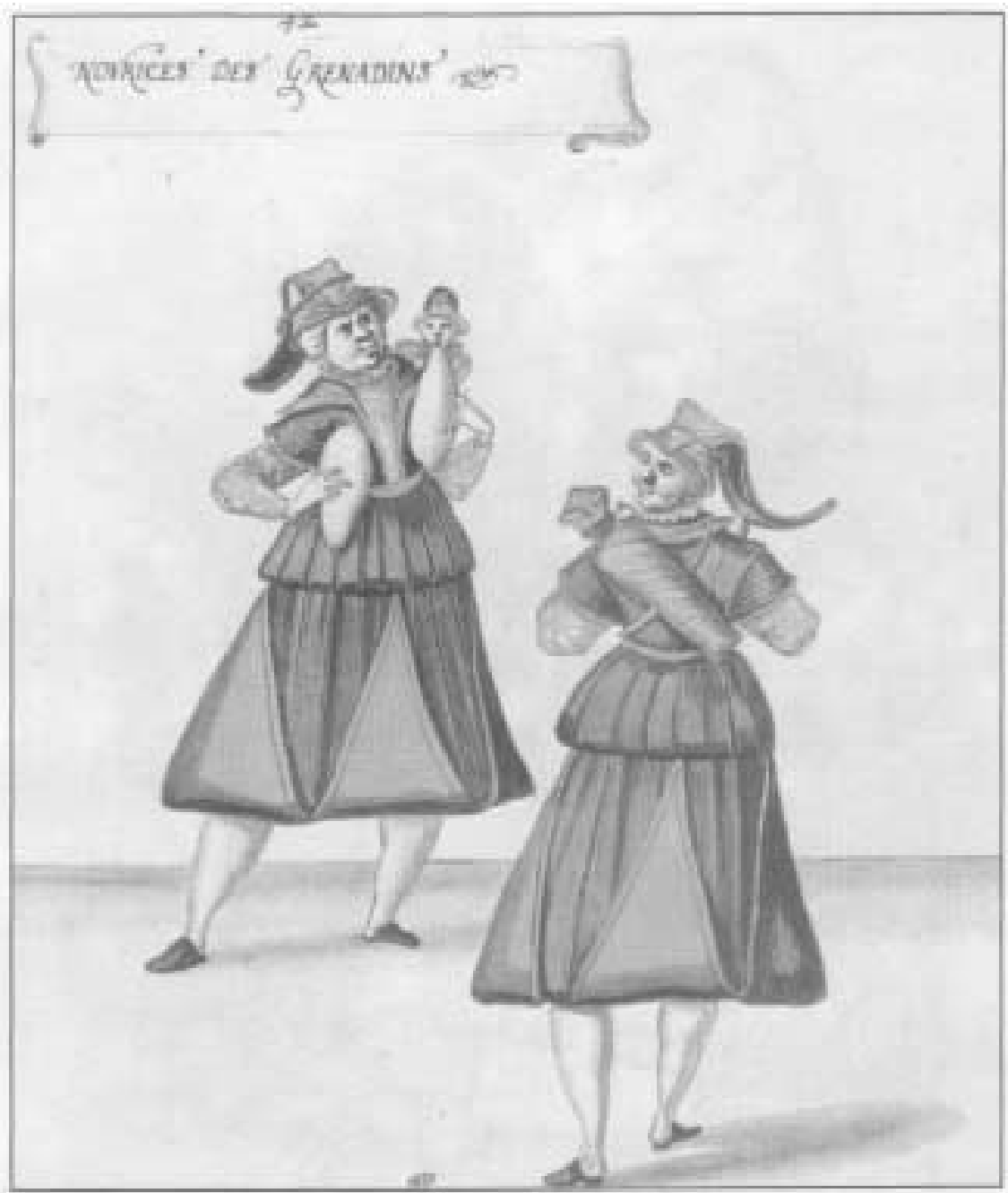

Fig 2. Daniel Rabel, costume drawing for the nurses of the 'Grenadins', 1626. Courtesy la Musée du Louvre. 


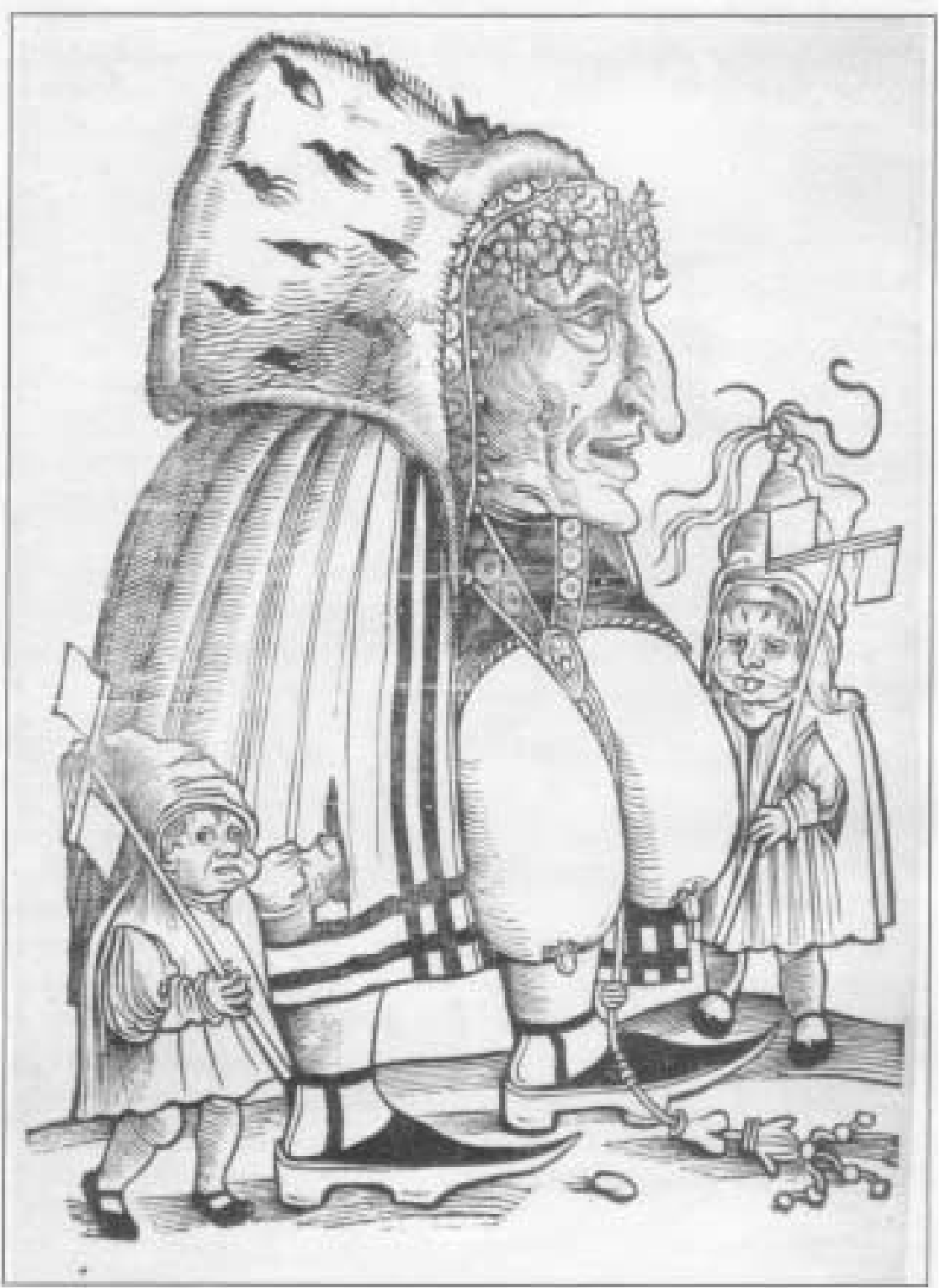

Fig 3. Hans Weiditz, Grotesque Woman with Children, woodcut, $c 1521$. Courtesy the British Museum. 
of an old woman, a crone-like wetnurse, accompanied by two small children. She is a version of the 'Somebody' motif, all large head and torso, featuring prominent, naked, pendulous breasts, perched directly on absurdly stumpy legs and feet. ${ }^{15}$ The figure wears a fur hood and a cape; beneath that is some kind of yoked garment with a collar and pendant, hanging between the breasts and trailing on the ground. Weiditz has given the face the exaggerated prominent features, folds, and wrinkles of the entire series of these figure woodcuts, but the grotesque exaggeration of the breasts does not match the age of the face: they are simply large and long, with nipples at their lower ends, pointing downwards. It is this feature of the caricature which Rabel particularly adopts in his costume design, with the added absurdity that as the breasts are now appendages of a costume, sewn and stuffed, they can be elevated without any change in their shape.

The appeal of the grotesque no doubt relies on some surprising but not entirely arbitrary substitution, in which we can observe some kind of analogical relationship: short legs for long ones, an exaggerated mask for a normally proportioned face, or, in Arcimboldo's compositions, a cucumber for a nose. In the case of the human body harmonious, symmetrical, and dignified order is subverted, and variations, extensions, and inversions of its parts and proportions are enjoyed as a festival sport, while its status as part of a material world is explored by confusing it, through masks and costuming, with other parts of that world, both organic and inorganic. Such visual enjoyment was well established in medieval Europe, as many carvings and illustrations attest, and it has persisted in varying forms in subsequent cultures. The entertainments of the European courts in the earlier seventeenth century gave the grotesque impulse expression in different degrees, and the French taste appears to have been considerably broader than the English, characteristic views of the respective national styles in drama notwithstanding.

The particular origins of Rabel's exuberant entertainments for the French court in the 1620s and 1630s lay partly in German art of a century earlier, which explores what one might call the energy of ugliness. The subjects are often folk or peasant life, and vigorous representations of feasting, dancing, and fighting abound. ${ }^{16}$ The turn from realistic treatment of such material to caricature, particularly as practised by Flötner, Schön, and Weiditz, produced the kind of fantasy which was given expression in the Edwardian entertainment of the bagpiping apes - a show which may quite possibly have taken its inspiration from a now vanished woodcut print. ${ }^{17}$ The Ballet Royal du Grand bal de la Douairière de Billebahaut of 1626 was a far more elaborate affair, with a series of processions and dances by exotic peoples come from all over the 
known and unknown worlds to pay homage to the strange noblewoman we see in fig $1 .{ }^{18}$ The extravagance of its visual inventions is remarkable, yet in copying earlier German prints Rabel acknowledged a continuing tradition of caricature and grotesquerie in graphic and theatrical art.

Notes

1 See W.R. Streitberger, Court Revels 1485-1559 (Toronto, 1994), 280, 293.

2 Streitberger, Court Revels, 293; A. Feuillerat, Documents Relating to the Revels at Court in the Time of King Edward VI and Queen Mary. Materialien zur Kunde des älteren Englischen Dramas, vol 44 (Louvain, 1914), 129-40.

3 See James Knowles, 'The "Running Masque” Recovered: A Masque for the Marquess of Buckingham c.1619-20,' English Manuscript Studies 1100-1700 8 (2000), 79-135; Timothy Raylor, 'The Lost Essex House Masque (1621): A Manuscript Text Discovered', English Manuscript Studies 1100-1700 7 (1998), 86-130; 'The Design and Authorship of The Essex House Masque (1621)', Medieval and Renaissance Drama in England 10 (1998), 218-37; The Essex House Masque of 1621 (Pittsburgh, 2000), especially 48-60.

4 In the designs for The Temple of Love (1635) Jones appears to have drawn on Rabel costume designs for the Ballet du Château de Bîcetre (1632) and for the Ballet de la Douairière de Billebahaut (1626). See John Peacock, The Stage Designs of Inigo Jones (Cambridge, 1995), 144-7.

5 Rabel's designs are illustrated in Margaret M. McGowan, L'art du ballet de cour en France 1581-1643 2nd ed (Paris, 1978), and The Court Ballet of Louis XIII (London, [1986]). For the English Nobody and Somebody tradition, see R.A. Foakes, Illustrations of the English Stage 1580-1642 (Stanford, 1985), 62-3, 94-5.

6 E. Fučíková et al (ed), Rudolf II and Prague (London, 1997), 607.

7 McGowan, Court Ballet, plates IX, X; catalogue \#47, \#106.

8 See J. Porcher (ed), Les Songes drolatiques de Pantagruel (Paris, 1959); Ann Lake Prescott, 'The Stuart Masque and Pantagruel's Dreams', English Literary History, 51 (1984), 407-30.

9 The French Renaissance in Prints, David Acton et al (Los Angeles and Paris, 1994), 402 [Marianne Grivel, 'Woodcuts \& the Rue Montorgueil'].

10 Margaret McGowan's description of the (coloured) sketch speaks of a 'grotesque female figure ... walking on blocks and wearing a black dress and orange underskirt; a transparent veil falls from her widow's bonnet' (Court Ballet, 88). 
11 I regret that my requests to the Schlossmuseum regarding reproductions and publication permission have not produced any reply. I therefore refer the reader to the reproductions of these prints in Max Geisberg, (rev. and ed. Walter Strauss, vol 4) The German Single-Leaf Woodcut 1500-1550, (New York, 1974), 1476, 1480.

12 The serpentine neck of the physician is used by Rabel particularly for a grotesque musical figure design for the Ballet du Sérieux et du Grotesque (a significant title) in 1627; see McGowan, Court Ballet, Plate X, \#112. Such serpentine distorted necks and swollen bellies appear in other contexts of Renaissance illustration: see, for example, the woodcut representation of 'Gula' (Gluttony) in an edition of Alciato's Emblemata produced in Lyons in 1550, with designs by Pierre Vase (facsimile ed, Menston, 1966), 98.

13 See Giulia Bartrum, German Renaissance Prints 1490-1550 (London, 1995), Plate 3; 88-97.

14 McGowan, Court Ballet, \#82.

15 The grotesque nurse in the early 1500 s perhaps had a parodic charge with more blasphemous power than at first appears, since the common contemporary iconographic figure of the nursing woman was the madonna lactans, the Virgin Mary feeding the infant Jesus.

16 See Keith Moxey, Peasants, Warriors, and Wives (Chicago, 1989).

17 In his Kunstbüchlin (Nuremberg, 1578), Jost Amman includes a design of a bagpipe-playing bear.

18 See McGowan, L'art du Ballet, Plates XVII-XX. 